\title{
THE SOCIETY OF DAIRY TECHNOLOGY
}

\author{
SOCIETY PUBLICATIONS
}

The following publications are currently available from the Society's offices

Cream Processing Manual

Price $£ 2.00$ incl. postage

Quality Control of Milk Products

Price $£ 2.00$ incl. postage
Pasteurising Plant Manual

Price $£ 1.00$ incl. postage

UHT Processing of Dairy Products

Price $£ 1.31$ incl. postage

Bottle Washing Booklet

Price 23p incl. postage

All enquiries to the Secretary, Society of Dairy Technology, 172A Ealing Road, Wembley, Middlesex, HA0 4QD.

The JOURNAL of the Society is published quarterly (January, April, July and October).

Subscription Rates: $£ 11.00$ per volume of four issues (USA and Canada $\$ 26.50$ per vol.), single issues $£ 3$. From the above address.

\section{INDIAN JOURNAL OF DAIRY SCIENCE}

1. Comparative utilization of feed nutrients in growing goats and calves by V. D. MUDGaL and (Miss) DALJIT KaUR

2. Nutritional evaluation of genetic materials of oats (Avenasativa) by chemical methods by RANDHIR SiNGH and K. PRADHAN

3. Genetic study on body weights of Tharparkar Friesian half bred females by H. K. B. PAREKH, N. K. DUBEY and V. K. TANEJA

4. A study on relationship of dry period with lactation yield in Tharparkar cattle by SHRI RAM, DAYA SINGH BALAINE and BALBIR SINGH

5. Seasonality of calving and its influence on economic character of Murrah buffaloes by M. GURNANI, R. NAGARCENKar, S. K. Gupta and AMARJit SiNGH

6. Inheritance of milkfat content in Red Sindhi Sahiwal and their Brown-Swiss crosses by D. S. CHAWLA and R. R. MishRA

7. Studies on livability of buffalo spermatozoa at $37^{\circ} \mathrm{C}$ for evaluating the viable life of spermatozoa and efficacy of diluents by BHUPAL SiNGH and D. P. SADHU
8. Variations in fat, unsaponifiable matter and cholesterol contents of goat milk by K. L. ARORA, M. P. BINDAL and M. K. JAIN

9. Release of components from buffalo casein micelles on acid treatment by M. P. GuPTA and N. C. GaNGULI 10. Chemical characterization of lipids of milk fat globule membrane fractions by G. P. SiNGH, J. ChatTARA and TAPAS K. RAY

11. Treatment of milk wastes by extended aeration by N. N. PILLA, H. D. PAsRiJa and R. K. BharadWaJ

12. Standardization of the industrial method of production of dried chhana by B. D. TIWARI and SUKUMAR DE

13. Prevalence of tuberculosis in animals of organised farms in Punjab by D. V. Joshi, D. R. Sharma, S. S. DHILLON and S. S. SODHI

Short Communications

Price: Rs. $40 /-(\$ 10.00$ or $\$ 4.00$ ) per annum.

Published by: Indian Dairy Association, IDA House, Sector IV, R. K. PuraM, New Delhi 110022 , INDIA. 


\section{MACHINE MILKING}

A monograph prepared and published by the National Institute for Research in Dairying, Reading, England. Publication date April-May 1977

The aim of this comprehensive book is to provide an authoritative but interesting assessment of current knowledge to research workers, manufacturers, advisers, veterinarians, students and interested farmers. Each chapter is substantially complete in itself and written at a technical level to suit the nature of the material. The authors of the chapters are members of the staff of the N.I.R.D. and others with whom they have worked closely.

\section{Contents (about 300 pages, 170 illustrations)}
Chap. I History and development
II Basic mechanics
III Description and performance of components
IV Maintenance and mechanical testing
V Action of the cluster during milking
VI Anatomy and physiology of the udder
VII Milking routines
VIII Machine milking in cowsheds and milking parlours
IX Machine milking and mastitis
X Cleaning and disinfection in milk production
XI Rubber and the milking machine
XII Milk cooling equipment

H. S. Hall

H. S. Hall

D. N. Akam

H. S. Hall

C. C. Thiel \& G. A. Mein

A. T. Cowie

F. H. Dodd \& T. K. Griffin

P. A. Clough

R. G. Kingwill, F. H. Dodd

\& F. K. Neave

Christina M. Cousins \&

C. H. McKinnon

J. G. Anderson \&

L. J. Coombs

J. B. Hoyle

Pre-publication price, including postage: $£ 6$ (US\$10) single copies $£ 4.80$ (US $\$ 8$ ) for 5 or more copies cash with order please

Obtainable from: The Librarian

N.I.R.D.

Shinfield

Reading RG2 9AT

England

Specimen page see over 


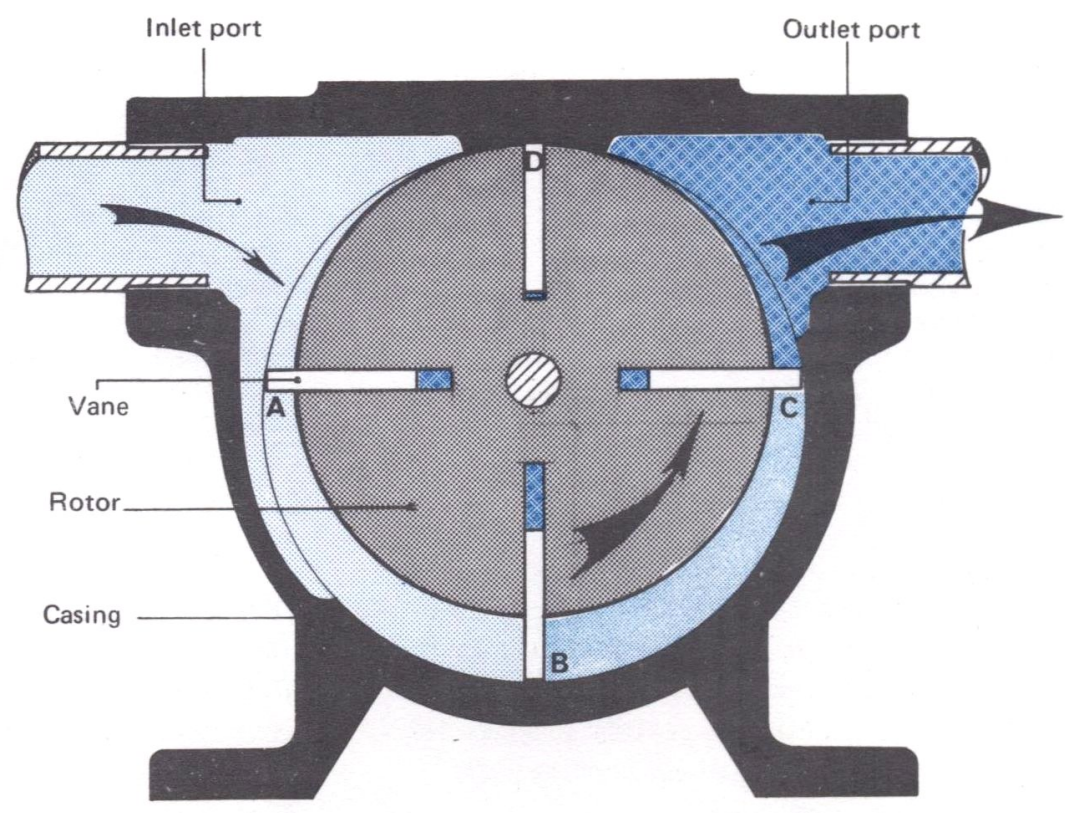

Fig III 2. Diagrammatic cross section of an oil sealed vacuum pump showing the principal components. Light blue represents air at inlet vacuum; dark blue, air being compressed and ejected to atmosphere.

demanding task and several types of pump are suitable. The positive displacement rotary pump is the type most commonly used. It is compact, robust and requires comparatively little maintenance.

\section{Oil lubricated vacuum pumps}

Fig III 2 shows a cross-section of a typical rotary vacuum pump. It consists of a horizontal cylindrical casing, with a rotor mounted eccentrically so that it is virtually in contact with the casing at one point of the circumference. The space between the rotor body and the casing is thus crescent shaped, and communicates through the elongated inlet port with the vacuum pipeline, and through the elongated outlet port with the exhaust pipe. The rotor has longitudinal slots, usually four, which house vanes free to slide radially as the rotor turns. The vanes, which are usually made of asbestos fibre composition, are kept in contact with the casing by centrifugal force. In some designs the vanes slide tangentially, the purpose being to reduce frictional losses.

As the rotor turns, pockets of air are enclosed between the vanes and transferred from the inlet to the outlet. In the diagram the space between vanes 


\section{DIRECTIONS TO CONTRIBUTORS}

\section{GENERAL}

Two copies of manuscripts should be sent to Dr M. E. Sharpe (The Journal of Dairy Research), National Institute for Research in Dairying, Shinfield, Reading, RG2 9AT, England. Submission of a paper will be held to imply that it reports unpublished original work, that it is not under consideration for publication elsewhere, and that if accepted for the Journal it will not be published elsewhere in any language, without the consent of the Editors.

\section{FORM OF PAPERS}

The author should follow these directions carefully, and consult a current issue of the Journal for guidance on details of typographical and other conventions.

Every paper should be headed with its title, the names and initials of the authors (women supplying one given name) and the name and address of the laboratory where the work was done.

Papers should be in English, using the spelling of the Shorter Oxford English Dictionary. They should be typed with double spacing, on one side only of the sheets, and with ample margins for editorial annotations.

Papers should in general be divided into the following parts in the order indicated: (a) Summary, brief and self-contained; (b) Introductory paragraphs, briefly explaining the object of the work but without giving an extensive account of the literature; (c) Experimental or Methods; $(d)$ Results; (e) Discussion and Conclusions; $(f)$ Acknowledgements without a heading; $(g)$ References. With some types of material headings other than $(c),(d)$ and $(e)$ may be preferable.

The use of footnotes should be avoided if possible. Underlining should be used only to indicate italics. Proper nouns, including trade names, should be given a capital initial letter. Wherever possible numerals should be used unless this leads to ambiguity. The typescript should carry the name and address of the person to whom the proofs are to be sent, and give a shortened version of the paper's title, not exceeding 45 letters and spaces, suitable for a running title in the Journal.

\section{TABLES}

Tables should be numbered and should carry headings describing their content. They should be comprehensible without reference to the text. They should be typed on separate sheets and their approximate positions in the text indicated. To minimize the cost of printing, the number and size of tables should be kept to an absolute minimum.

\section{ILLUSTRATIONS}

Line drawings, which must be originals, should be numbered as Figures and photographs as Plates, in Arabic numerals. Drawings should be in Indian ink, on Bristol board or cartridge paper. However, a technique which may be more convenient to authors is to use a double-sized piece of tracing paper, or translucent graph paper faintly lined in blue or grey, folded down the centre with the drawing on one half and the other half acting as a flyleaf.

Attached to every figure and plate there should be a translucent flyleaf cover on the outside of which should be written legibly: (a) title of paper and name of author; (b) figure or plate number; $(c)$ the figures and lettering, which are intended to appear on the finished block, in the correct positions relative to the drawing underneath. Each paper should have a separate typed sheet listing figure and plate numbers with their legends, and the approximate positions of illustrations should be indicated in the text.

The photographs and diagrams should be about twice the size of the finished block and not larger overall than the sheets on which the paper itself is typed. For a figure measuring $250 \mathrm{~mm} \times 150 \mathrm{~mm}$ all lines, axes and curves should be $0.4 \mathrm{~mm}$ thick, thus Graph symbols in order of preference are $\mathrm{O} \boldsymbol{\bullet}, \Delta \boldsymbol{\Delta}$, $\square \mathbf{n}, \times+$, and for a $250 \mathrm{~mm} \times 150 \mathrm{~mm}$ graph the circles should be $3 \mathrm{~mm}$ in diam. The triangles should be equilateral of $3 \mathrm{~mm}$ side, and the squares also of $3 \mathrm{~mm}$ side. The crosses should have lines $3 \mathrm{~mm}$ long at right angles. Scale marks on the axes should be on the inner side of each axis and should be $3 \mathrm{~mm}$ long.

\section{SHORT COMMUNICATIONS}

Short communications or notes of not more than 2500 words or the equivalent space in print and without a summary will also be published.

\section{REFERENCES}

In the text, references should be quoted by whichever of the following ways is appropriate: Arnold \& Barnard (1900); Arnold \& Barnard (1900a); Arnold \& Barnard $(1900 a, b)$; (Arnold \& Barnard, 1900). Give all the surnames of 3 authors at the first mention, but in subsequent citations and in all cases where there are more than 3 authors give only the first surname (e.g. Brown et al.) provided that there is no possible ambiguity.

References should be listed alphabetically at the end of the paper. Titles of journals should be given in full, authors' initials should be included, and each reference should be punctuated in the typescript thus: Arnold, T. B., Barnard, R. N. \& Compound, P. J. (1900). Journal of Dairy Research 18, 158. References to books should include names of authors, year of publication, title, names of editors, town of publication and name of publisher in that order, thus: Arnold, T. B. (1900). Dairying. London: Brown and Chester.

It is the duty of the author to check all references.

\section{UNITS, SYMBOLS AND ABBREVIATIONS}

SI units must be used, as explained in British Standards Institution publication PD 5686:1972, The use of SI units. Until SI units are widely understood, it is permissible to give the equivalent value in other units in parenthesis. Symbols and abbreviations used are those of British Standard 1991: Part 1: 1967. Letter Symbols, Signs and Abbreviations.

\section{DESCRIPTIONS OF SOLUTIONS}

Normality and molarity should be indicated thus: $\mathrm{N}-\mathrm{HCl}, 0 \cdot 1 \mathrm{M}-\mathrm{NaH}_{2} \mathrm{PO}_{4}$. The term ' $\%$ ' means $\mathrm{g} / 100 \mathrm{~g}$ solution. For $\mathrm{ml} / 100 \mathrm{ml}$ solution the term ' $\%(\mathrm{v} / \mathrm{v})^{\text {" }}$ should be used and for $\mathrm{g} / 100 \mathrm{ml}$ solution the correct abbreviation is ' $\%(w / v)$ '.

\section{REPRINTS}

Order forms giving quotations for reprints are sent to authors with their proofs. 


\section{CONTENTS}

o BItuARY: Emeritus Professor H. D. Kay, C.B.E. Ph.D. (Cantab), D.Sc. (Manchester), F.R.S.

ORIGINAL ARTICLES

Estimation of the prevalence of udder infection in dairy herds based on a singlequarter sample from each cow in the dairy herd.

G. P. Y. CLARKE and J. OLIVER

The concentration of lactate in relation to other components of bovine mammary secretion during premature regression and after resumption of milking

R. I. MACKIE, W. H. GIESECKE, H. L ÜCK and P. A. DE VILLIERS.

An improved method for the quantitative fractionation of casein mixtures using ion-exchange chromatography

D. T. DA VIES and A. J. R. LAW

Progressive changes in individual milk protein concentrations associated with high somatic cell counts

M. ANDERSON and A. T. ANDREWS

Kinetics of the heat-induced aggregation of milk protein J. C. D. WHITE and A. W. M. SWEETSUR

Effect of urea on the heat coagulation of the caseinate complex in skim-milk D. D. MUIR and A. W. M. SWEETSUR

Chemical changes in ultra-heat-treated milk during storage. I. Hydrolysis of casein by incubation with pronase and a peptidase mixture

A. B. MÖLLER, A. T. ANDREWS and G. C. CHEESEMAN

Chemical changes in ultra-heat-treated milk during storage. II. Lactuloselysine and fructoselysine formation by the Maillard reaction

A. B. MÖLLER, A. T. ANDREWS and G. C. CHEESEMAN

Chemical changes in ultra-heat-treated milk during storage. III. Methods for the estimation of lysine and sugar-lysine derivatives formed by the Maillard reaction A. B. MÖLLER, A. T. ANDREWS and G. C. CHEESEMAN

Properties of aseptically packed ultra-heat-treated milk. Electron microscopic examination of changes occurring during storage

A. T. ANDREWS, B. E. BROOKER and D. G. HOBBS

An examination of the factors affecting the reverse osmosis of milk with special reference to deposit formation

P. J. SKUDDER, F. A. GLOVER and M. L. GREEN

Dipeptide utilization by starter streptococci

B. A. LAW

Selective denaturation of milk coagulants in 5 M-urea

D. M. MULVIHILL and P. F. FOX

Seasonal variations of copper and iron in Irish milk and butter

J. J. MURPHY, D. R. HEADON and W. K. DOWNEY

Denaturation of porcine pepsin during Cheddar cheese manufacture

A. M. O'KEEFFE, P. F. FOX and C. DALY

SHORT COMMUNICATIONS

Electrical conductivity of milk from goats of the Beetal breed

G. S. SHARMA and N. K. ROY

Inverse relationship between the electrolyte concentration and the content of fat, protein, and lactose in the normal milks of individual cows from the same herd

M. OSHIMA and H. FUSE

Effect of sulphydryl-blocking agents on the primary phase of chymosin action

on heated casein micelles and heated milk

S. I. SHALABI and J. V. WHEELOCK

Cheddar cheese aroma - the effect of selectively removing specific classes of compounds from cheese headspace

D. J. MANNING and J. C. PRICE

Observations on the primary phase of milk coagulation by rennet under

standardized conditions

KL. GUTHY and G. NOVAK

Effect of heat on $\alpha$-lactalbumin and $\beta$-lactoglobulin

A. A. ELFAGM and J. V. WHEELOCK

A simple method for the isolation of a phosphopeptide from bovine $a_{81}$-casein D. W. WEST

Micro-determination of lead and cadmium in pasteurized market milks by

flameless atomic absorption spectroscopy using a base digest P. J. BARLOW

Reviews of the progress of Dairy Science: bovine salmonellosis

c. WRAY and W. J. SOJKA

(c) Proprietors of The Journal of Dairy Research 1977

Printed in Great Britain at the University Press, Cambridge 